\title{
Larangan Maisīr dalam Al-Qur'an dan Relevansinya dengan Perekonomian
}

\author{
Dewi Laela Hilyatin \\ IAIN Purwokerto \\ Jl., A. Yani No. 40-A Purwokerto, Jawa Tengah \\ dewilaelahilyatin@iainpurwokerto.ac.id
}

\begin{abstract}
Gambling (maisīr) is strictly prohibited by the Qur'an. However, in reality, the practice of gambling has always existed from time to time, even from its simple form to its complex form. The prohibition of gambling in the Qur'an is stated in three verses: Al Bāqarah: 219, Al Māidah: 90 - 91. Of the three verses, it is explained that gambling (maisir) benefits humans, but the harm is much greater. This is very relevant from the economic point of view. Gambling does not increase economic growth, because it does not produce output, what only happens is the movement of money and goods between individuals. Gambling also does not increase productivity, there is only a waste of energy and time, even gambling can be called a killing time. In the context of the state, the activity of gambling in the aggregate greatly reduces national income, not the opposite.
\end{abstract}

Keyword: Al-Qur'an, Maisir/Gambling, and Economy

Abstrak

Perjudian (maisīr) sangat dilarang oleh Al-Qur'an. Namun demikian, dalam kenyataannya, praktek perjudian selalu ada dari masa ke masa, bahkan dari bentuknya yang sederhana sampai bentuknya yang kompleks. Pelarangan judi dalam Al-Qur'an tertuang dalam tiga ayat yaitu: QS. Al Bāqarah: 219, QS. Al Māidah ayat 90, dan 91. Dari ketiga ayat tersebut dijelaskan bahwa perjudian (maisīr) memberikan manfaat kepada manusia, akan tetapi madharatnya jauh lebih besar. Hal ini sangat relevan dengan sudut pandang perekonomian. Judi tidak meningkatkan pertumbuhan ekonomi, karena tidak menghasilkan output, yang terjadi hanya lah perpindahan uang dan barang antar individu. Judi juga tidak menumbuhkan produktivitas, yang ada hanya penghabisan tenaga dan waktu para pelakunya secara sia-sia, bahkan judi bisa disebut sebagai killing time. Dalam konteks negara, maka ativitas perjudian, secara agregat sangat mengurangi pendapatan nasional, bukan sebaliknya.

Kata Kunci: Al-Qur’an, Maisir/Judi, dan Perekonomian

\section{A. Pendahuluan}

Al-Qur'an sebagai Kalamullah, wahyu yang diturunkan kepada Nabi Muhammad, sebagai petunjuk dan sumber ajaran moral bagi seluruh umat Islam. Untuk bisa 
mengakses kepetunjukkan Al-Qur'an maka umat Islam harus menafsirkannya, dan oleh karena Al-Quran adalah pesan Allah yang memiliki kode dan saluran berupa bahasa Arab, maka untuk meretas kode tersebut dibutuhkan sebuah analisis teks (Aziz, 2020, p. 48). Posisi al-Qur'an sebagai sumber ajaran moral dan petunjuk, tentunya menjadikan al-Qur'an menempati posisi sentral dalam pengembangan ilmu keislaman dan pemandu dinamika umat Islam sepanjang zaman. Oleh karena itu upaya untuk memahami AlQur'an harus terus dilakukan. Dalam kerangka ini lah, artikel ini ditulis.

Dengan mengambil topik maisir/judi, tulisan ini akan mengkaji makna dan hakikat perjudian, pelarangan judi dan alasan ('illatul hukmi) pelarangannya perspektif Al-Qur'an, serta relevansinya dari sudut pandang teori ekonomi. Topik judi ini diangkat, salah satunya didasarkan pada pertimbangan selalu meningkatnya kriminalitas perjudian dari tahun ke tahun, khususnya di negara Indonesia. Hal ini sebagaimana tergambar pada tabel data krimanilatias di bawah ini:

Tabel data tingkat kriminalitas di Indonesia

\begin{tabular}{|c|c|c|c|c|c|c|c|}
\hline \multirow[t]{2}{*}{ No } & \multirow[t]{2}{*}{ Jenis kejahatan } & \multicolumn{3}{|l|}{ Jumlah } & \multicolumn{3}{|c|}{ Prosentase } \\
\hline & & 2011 & 2014 & 2018 & 2011 & 2014 & 2018 \\
\hline 1 & Pembunuhan & 1585 & 1739 & 1799 & 2,02 & 2,12 & 2,14 \\
\hline 2 & Penganiayaan & 4171 & 4047 & 5092 & 5,31 & 4,92 & 6,07 \\
\hline 3 & Perkosaan & 2122 & 2050 & 2851 & 2,70 & 2,49 & 3,40 \\
\hline 3 & $\begin{array}{l}\text { Pencurian dengan } \\
\text { kekerasan }\end{array}$ & 2233 & 2963 & 2821 & 2,96 & 3,61 & 3,36 \\
\hline 4 & Pencurian & 28912 & 33739 & 37778 & 36,78 & 41,05 & 45,01 \\
\hline 5 & $\begin{array}{l}\text { Penipuan/ } \\
\text { penggelapan }\end{array}$ & 5603 & 7244 & 8620 & 7,13 & 8,81 & 10,27 \\
\hline 6 & Pembakaran & 518 & 874 & 1050 & 0,66 & 1,06 & 1,25 \\
\hline 7 & $\begin{array}{l}\text { Perdagangan } \\
\text { orang }\end{array}$ & 119 & 122 & 124 & 0,15 & 0,15 & 0,15 \\
\hline 8 & $\begin{array}{l}\text { Penyalahgunaan/ } \\
\text { pengedaran } \\
\text { narkoba }\end{array}$ & 4103 & 5931 & 12579 & 5,22 & 7,22 & 14,99 \\
\hline 9 & Perjudian & 7984 & 11079 & 12842 & 10,16 & 13,48 & 15,30 \\
\hline
\end{tabular}

Sumber: (Statistik Kriminal 2019.Pdf, n.d., p. 142)

Berdasar tabel di atas, sekali lagi jelas sekali bahwa kriminalitas perjudian selalu mengalami peningkatan dari tahun ke tahun, khususnya di negara Indonesia. Memang, 
negara Indonesia adalah negara dengan penduduk muslim terbesar di dunia, yang dengan ini berati mayoritas penduduknnya berpedoman pada Kitab Suci Al-Qur'an, dan Al-Qur'an jelas-jelas melarang perjudian. Namun, kriminalitas perjudian selalu meningkat. Hal ini barangkali bukan karena Al-Qur'annya, tetapi bisa jadi karena alas an pertumbuhan ekonomi. Atau dengan kata lain, perjudian meningkat, sekalipun di negara yang mayoritas penduduknya beragama Islam, karena ada anggapan bahwa perjudian bisa meningktkan pertumbuhan ekonomi. Di sini lah signifikansi dan relevansi artikel ditulis.

\section{B. MAisir (JUdi): Pengertian dan hakikatnya}

Kata judi pada umumnya disamakan dengan al-maisir ( الميسر ) kata maisīr berasal dari akar kata al-yasr ( اليسر ) yang berarti "wajibnya sesuatu bagi pemiliknya". Akar kata yang lain al-yasar yang berarti kekayaan juga berasal dari kata al-yusr yang berarti muda. (Al-Qurthubiy, 1372, p. 53).

Maisīr secara harfiah bermakna mendapatkan sesuatu atau keuntungan dengan sangat mudah tanpa bekerja keras. Sesuatu hal yang mengandung unsur judi, permainan berisiko atau taruhan (Ascarya, 2013, p. 20). Dalam al-Quran Istilah lain yang digunakan adalah kata 'azlam` yang berarti praktek perjudian (Rudiansyah, 2020, p. 102). Senada dengan makna di atas maisīr adalah bentuk permainan yang menempatkan salah satu pihak harus menanggung beban pihak lain akibat permainan tersebut (al Mashri, 2001).

Beberapa makna yang terkandung dalam kata Maisir di antaranya: lunak, tunduk, mudah, keharusan, kaya, membagi-bagi, dan lain-lain. Ada juga yang mengatakan bahwa kata maisir berasal dari kata yasara (يسر) berarti keharusan. Keharusan bagi seseorang yang kalah dalam berjudi untuk menyerahkan yang dipertaruhkan kepada pihak pemenang. Ada yang mengatakan bahwa al-maisīr (الميسر) berasal dari kata yusrun ( يُسرِ ) yang berarti mudah. Bahwa maisīr atau judi merupakan upaya dan cara untuk mendapatkan rezeki dengan mudah, tanpa susah payah (Rohim, 2020, p. 19).

Adapun secara terminologi, Judi adalah segala bentuk permainan dengan menggunakan pertaruhan (uang, barang, dan lain-lain), yang kalah harus membayar kepada yang menang. Secara lebih terperinci, Hamidi menjelaskan bahwa judi dapat 
dimaknai sebagai perpindahan properti melalui peluang atau untung-untungan. Dalam hal ini, ada tiga elemen pokok yang mendasari permainan judi yaitu: (Hamidi, 2012, p. 223)

1. Menempatkan uang atau sesuatu yang bernilai karena taruhan

2. Melibatkan sampai tingkat tertentu peluang yang terjadi secara acak yang mungkin dihitung atau tidak.

3. Hadiah yang diperebutkan berasal dari Sebagian uang atau barang yang dijadikan sebagai taruhan.

Secara lebih komprehensif, Freeman juga menjelaskan bahwa judi memiliki lima karakteristik, yaitu:(Freeman, 1907, pp. 76-91)

1. Hadiah yang disediakan untuk pemenang diambil dari kantong peserta yang kalah.

2. Keterkaitan antara taruhan dan hadiah bukan karena kondisi alamiah dari kehidupan sosial, tetapi lebih karena kans bukan karena berdasarkan alasan logis (misal: memenangkan lomba menulis atau olimpiade sains).

3. Peluang atau nasib menjadi bagian inti.

4. Praktik judi menyebabkan perilaku pelakunya disorganized

5. Masyarakat tidak menerima manfaat, karena tidak terjadi penciptaan produk barang atau jasa baru. Sebaliknya memberikan dampak buruk bagi mereka yang terkait.

Selanjutnya, mengenai hakikat perjudian, pada dasarnya dari zaman dahulu hingga sekarang, prinsip judi tidak lah berubah, yang berubah hanyalah wahana, bentuk, dan sarananya. Praktek perjudian tersebut bisa berupa undian, segala bentuk taruhan, lotre, permainan, dan lain-lain; dari bentuknya yang sederhana sampai pada bentuknya yang sangat kompleks. Oleh karena, praktek perjudian itu berubah-ubah, maka hakikat judi tidak mengacu pada satu bentuk atau satu praktek tertentu, melainkan mengacu pada prinsip atau unsur tertentu. Dengan ini, satu praktek bisa disebut sebagai judi, jika di dalam praktek tersebut ada unsur-unsur tersebut. Adapun unsur-unsur yang dimaksud adalah:(Sahroni \& Karim, 2017, pp. 119-120)

1. Taruhan (murahanah/ mukhatarah) dan mengadu nasib yang mengakibatkan pelaku menang atau kalah.

2. Pelaku maisir mempertaruhkan hartanya tanpa imbalan (muqabil). Pada permainan judi yang dipertaruhkan adalah uang yang diserahkan, sedangkan pada bisnis yang dipertaruhkan adalah risiko bisnis dan kerja.

3. Pemain judi yang menang mengambil hak pemain yang kalah, karena setiap pemain tidak saling memberi manfaat. 
4. Pelaku hanya memiliki niat dengan mengadu nasib untuk mencari uang, tidak ada tujuan lain.

\section{Pelarangan maisir (JUdi) Dalam al-QuR'an}

Ada tiga ayat dalam Al-Qur'an yang menjelaskan tentang maisir yaitu QS. Al Baqarah: 219, QS. Al Maidah ayat 90 dan QS. Al Maidah ayat 91. Berikut adalah kutipan dari ketiga ayat tersebut:

1. QS. Al-Baqarah: 219:

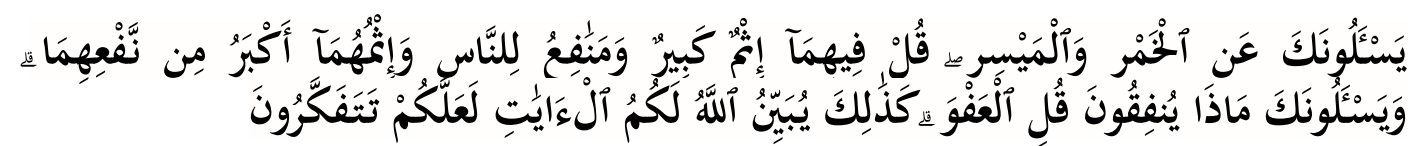

Mereka bertanya kepadamu tentang khamar dan judi. Katakanlah: "Pada keduanya terdapat dosa yang besar dan beberapa manfaat bagi manusia, tetapi dosa keduanya lebih besar dari manfaatnya". Dan mereka bertanya kepadamu apa yang mereka nafkahkan. Katakanlah: "Yang lebih dari keperluan". Demikianlah Allah menerangkan ayat-ayat-Nya kepadamu supaya kamu berpikir.

2. QS. Al-Maidah: 90:

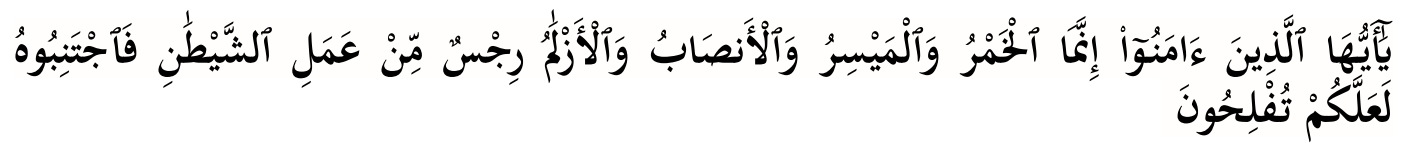

Hai orang-orang yang beriman, sesungguhnya (meminum) khamar, berjudi, (berkorban untuk) berhala, mengundi nasib dengan panah, adalah termasuk perbuatan syaitan. Maka jauhilah perbuatan-perbuatan itu agar kamu mendapat keberuntungan.

3. QS. Al-Maidah: 91

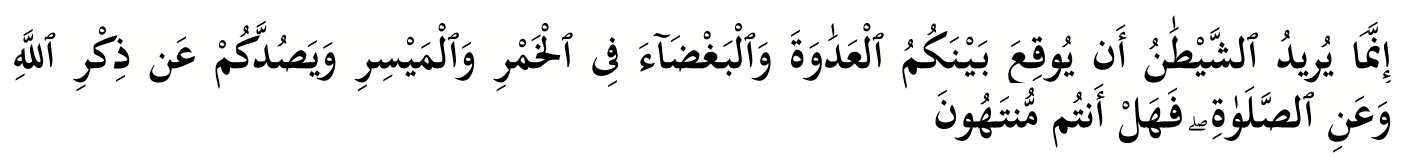

Sesungguhnya syaitan itu bermaksud hendak menimbulkan permusuhan dan kebencian di antara kamu lantaran (meminum) khamr dan berjudi itu, dan menghalangi kamu dari mengingat Allah dan sembahyang; maka berhentilah kamu (dari mengerjakan pekerjaan itu). 
Adapun asbabun nuzul dari ketiga ayat tentang maisir/judi di atas adalah: (Al Hamsyi, 1999, p. 200)

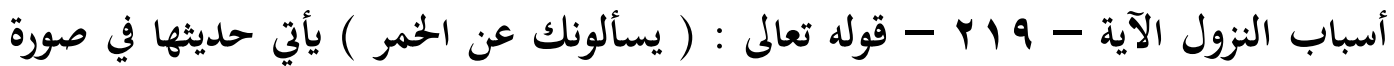

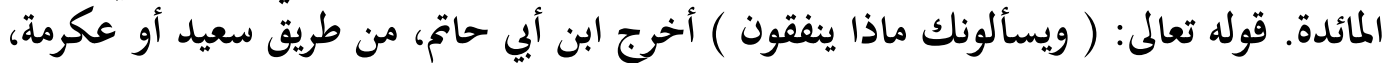

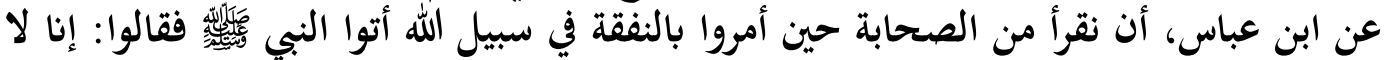

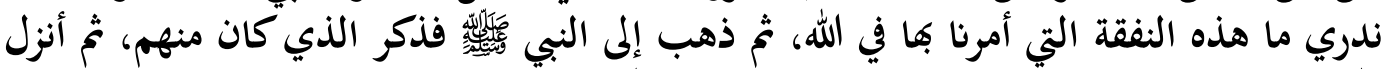

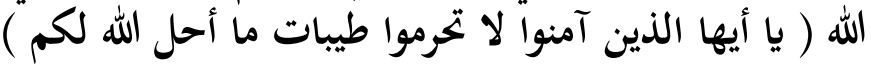

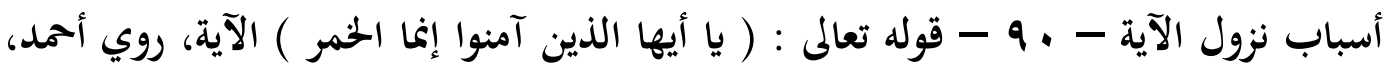

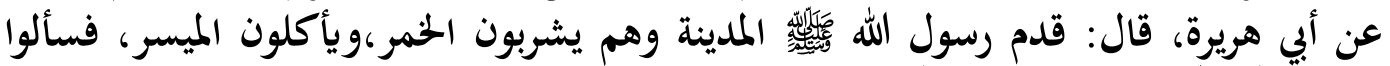

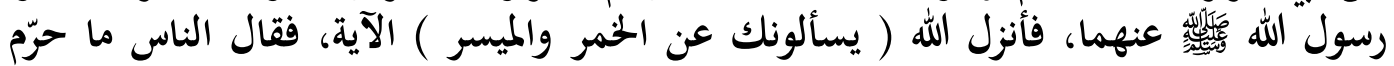

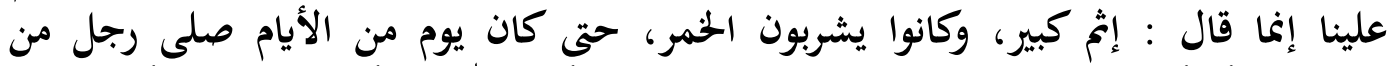

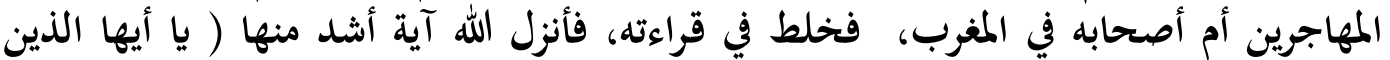

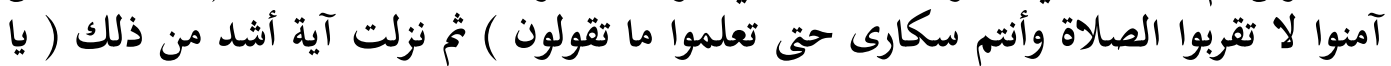

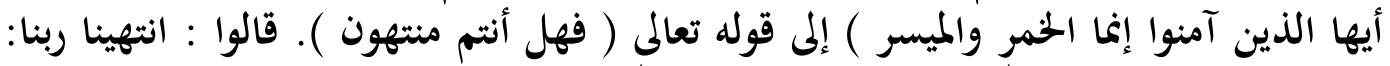

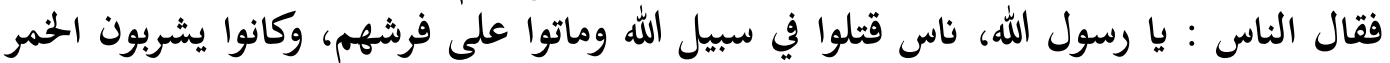

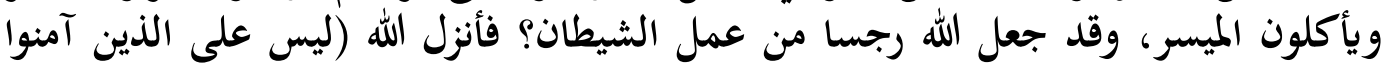

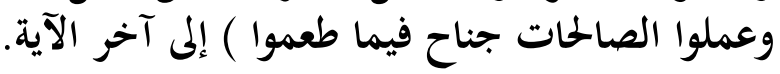

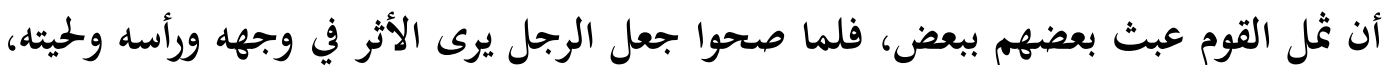

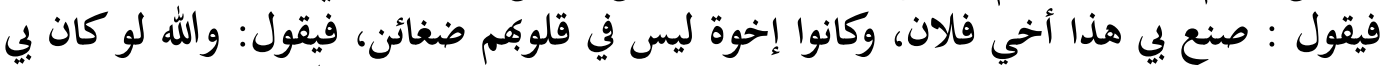

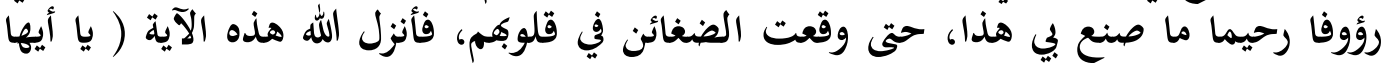

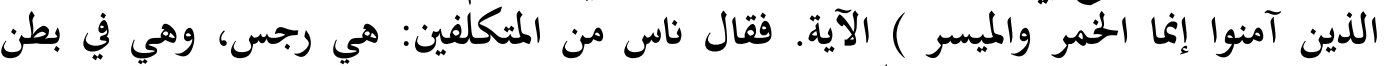

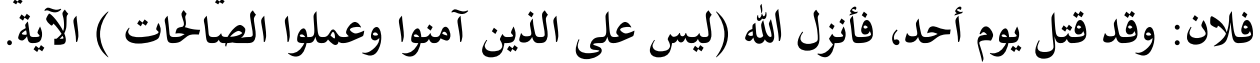

Diriwayatkan oleh Imam Ahmad dari Abu Hurairah, ia berkata: Rasulullah datang ke Madinah dan orang orang sedang minum khamr dan makan dari hasil judi. Kemudian mereka bertanya kepada Rasul tentang khamr dan maisir, lalu turunlah firman Allah (QS. Al-Baqarah: 219), kemudian orang orang berkata khamr dan maisir ini tidak diharamkan bagi kita, tetapi hanya dosa besar. Karena belum diharamkan mereka tetap minum khamr dan makan dari hasil judi. Suatu hari ada salah seorang laki laki menjadi imam temannya, dan salah bacaannya ketika shalat. Kemudian Allah menurunkan ayat yang lebih tegas (syadid) dari ayat sebelumnya. Bahwa seseorang jika akan shalat maka mereka tidak boleh dalam kondisi mabuk, sehingga kamu bisa memahami dan membedakan apa yang kamu katakan. Kemudian turun lagi ayat yang lebih syadid dari yang sebelumnya. Seseorang pergi ke medan perang, dia meninggal di atas tempat tidur 
(tidak ketika berperang), sedangkan orang tersebut dalam kondisi sedang meminum khamr dan bermain judi. Maka turunlah ayat yang mengharamkan khamr dan judi, dan perbuatan itu seperti perbuatan syetan.

Berdasarkan paparan ayat-ayat pelarangan maisir/judi di atas, jelas bahwa pelarangan maisir/judi bersandingan dengan pelarangan minum khamr. Hal ini karena dua kegiatan ini, tidak terpisah antara satu dengan lainnya; di mana ada perjudian di situ ada minum khamr, dan atau sebaliknya. Judi dan minuman keras menjadi satu paket karena kedua hal ini adalah kebiasaan masyarakat jahiliyah. Di samping itu, pelarangan judi dan khamr juga dilakukan secara bertahap. Hal ini, karena perjudian dan mabokmabokan sudah menjadi tradisi yang melekat pada masyarakat Jahiliyyah, sehingga butuh strategi dan metode pentahapan untuk bisa menerapkan aturan pelarangan keduanya secara ketat (haram). Dengan kata lain, larangan minum khamar dan judi, diturunkan secara berangsur-angsur, karena bagi orang Arab kedua hal tersebut telah menjadi adat kebiasaan sejak zaman jahiliah. Jika dilarang sekaligus, dikhawatirkan akan sangat memberatkan bagi mereka (Al-Ma'idah - المآئدة | Qur'an Kemenag, n.d.). Dalam The Encyclopedia of Islam juga digambarkan bahwa judi atau lebih dikenal dengan qimar pada masa jahiliyah sudah menjadi budaya (endemic) dilakukan dimanapun dengan model yang beraneka macam.(Hamidi, 2012, p. 244)

Sebagaimana disebutkan dalam QS. al-Baqarah: 219 bahwa Allah belum melarang judi dan minum khamr. Al-Qur'an melihat setting budaya masyarakat setempat. Di situ hanya disebutkan bahwa keduanya (judi dan khamr) memiliki beberapa manfaat (مَنَافْفُعُ) tidak hanya satu manfaat, tetapi juga memiliki madharat,

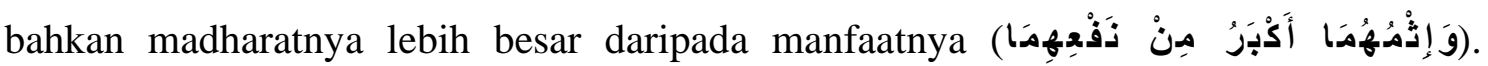
Dengan kata lain bahwa al Qur'an telah mengenalkan metodologi risk-return atau costbenefit.

Selanjutnya, QS. Al-Maidah: 90 dan 91 disebutkan bahwa khamr dan maisir merupakan pekerjaan setan dan wajib dijauhi. Keduanya (khamr dan judi) selalu menimbulkan kebencian dan permusuhan di anvara sesama dan juga akibat yang lebih fatal adalah lupa dengan Allah. Dengan demikian, pada QS. Al-Maidah: 90-91 ini, AlQur'an menyatakan secara tegas bahwa minuman keras (khamr) dan judi (maisir) adalah dilarang (diharamkan). 
Adapun mengenai illatul hukmi dilarangnya maisir/judi oleh Al-Qur'an, berikut ini adalah penjelasan dari para mufassir. Ali ash-Shabuni menjelaskan bahwa hikmah disyariatkannya maisir/judi adalah karena maisir/judi dapat menimbulkan permusuhan dan kebencian antar pemain, melupakan seseorang dari mengingat Allah dan shalat, merusak masyarakat karena dapat menurunkan etos kerja, menjadikan orang bermalasmalasan dengan menunggu keuntungan tanpa usaha dan rasa lelah, menghancurkan keluarga, menjadikan seseorang bangkrut, dan terkadang membuat orang mengakhiri hidupnya (Ash-Shabuni, 1980, p. 281). Sedangkan Mushtafa al-Maraghi, dalam Kitab Tafsir al-Maraghi, menjelaskan bahwa maisir/judi dapat menimbulkan kecanduan dan kepenasaranan, sehingga penjudi yang kalah akan terus menantang lawannya untuk berjudi, dengan harapan ada kesempatan untung menang. Keduanya tidak akan pernah berhenti berjudi, sampai harta mereka habis dan menjadi miskin (Al-Maraghi, 2001, p. 14). Tafsir Kemenag RI juga menekankan bahwa harta yang berputar di meja judi, walaupun jumlahnya banyak tetapi harta itu merupakan harta yang diharamkan. Harta tersebut tidak akan mendatangkan kebahagiaan, ketentramanm dan kesejahteraan kahir dan batin. Secara lahiriah mungkin pelaku judi menjadi orang kaya, tetai pada hakikatnya kekayaan itu tidak membawa keberkahan, kedamaian, dan kesejahteraan dalam hidup serta kebaikan amal sosial (Kemenag RI, 2012, p. 104). Terkhir, M. Quraish Shihab secara lebih detail dalam Tafsir al-Mishbah menjelaskan bahwa menjauhi perjudian adalah dalam konteks keburukan yang dikandung sesuai dengan sifat masing-masing larangan itu. Menjauhi perjudian adalah menjauhinya dari segi taruhannya. Menurut Quraish Shihab perjudian menyebabkan keburukan yang cukup besar. Dengan kemenangan atau kekalahan dalam berjudi menjadika pelaku terpaku dan terpukau untuk mengahabiskan waktunya memperoleh harta yang lebih banyak untuk mengganti kerugiannya. Hal inilah yang dimaksud perjudian dapat menghalangi seseorang mengingat Allah (beribadah dan berdzikir) (Shihab, 2004, pp. 193-195).

Berdasar penafsiran para ulama (mufassir) terhadap ayat-ayat larangan maisir/judi di atas, maka dapat disarikan bahwa ada illatul hukmi dilarangnya maisir/judi, di antaranya adalah adanya unsur taruhan, merugikan salah satu pihak, menimbulkan permusuhan, menimbulkan kecanduan dan rasa penasaran, menyebabkan lupa kepada 
Allah, dan menyebabkan hilangnya keberkahan. Dengan ini, para ulama bersepakat bahwa bahwa maisir/judi -berdasar kajian terhadap ayat-ayat di atas- adalah haram.

\section{Relevansi ayat-Ayat larangan Judi Dengan Perekonomian}

Berdasar pada QS. Al-Baqarah: 219, disebutkan bahwa di dalam perjudian ada manfaat dan madharat, akan tetapi madharatnya lebih besar dari manfaatnya, maka hal ini juga selaras dengan analisis dalam perekonomian. Disebutkan bahwa maisir/judi memiliki dampak positif dan negatif. Di antara dampak positif dari perjudian adalah:

a. Peningkatan ekonomi: tempat perjudian wajib membayar pajak kepada negara, maka secara otomatis akan meningkatkan pendapatan negara. Selain itu dibukanya tempat perjudian akan mendatangkan wisatawan mancanegara ke Indonesia. Dibukanya tempat perjudian akan membuka lowongan pekerjaan, berakibat pada penurunan angka pengangguran.

b. Pendapatan keluarga: apabila ada seorang anggota keluarga yang bisa bermain judi secara professional dan mahir, serta dia sukses secara ekonomi. Pasti pendapatan keluarga tersebut juga akan meningkat.

c. Hiburan: dengan dilegalkannya perjudian, maka ini akan menjadi tempat hiburan yang sebenarnya, dan menghilangkan stress serta kecemasan.

Sedang dampak negatif dari maisir/judi adalah:

a. Masalah keuangan: permainan judi dilakukan dengan mempertaruhkan sejumlah dana yang cukup besar, karena permainan ini sifatnya untung-untungan dan sangat berisiko, mereka yang tidak beruntung akan kehilangan semua dananya. Herannya lagi mereka yang sudah kalah tidak menyerah untuk mencoba keberuntungan itu, akibatnya jika tetap tidak beruntung maka kerugian yang ditanggung sangat besar.

b. Ketergantungan/Kecanduan: permainan judi memberikan efek ketergantungan, seperti meminum alkohol. Apalagi bagi mereka yang sudah pernah menang. Bermain judi membuat si pemain ketagihan, dan parahnya lagi mereka sangat yakin bahwa suatu saat mereka pasti akan menang walaupun sudah pernah kalah dan kehilangan semua hartanya.

c. Tingkat Kejahatan: di daerah yang banyak permainan judinya, biasanya tingkat kejahatannya juga meningkat. Pemain yang kalah karena frustasi mereka akan memberikan efek domino kejahatan kejahatan lain di sekitarnya. Pemain yang menang akan berusaha menyuap aparat atau pemerintah untuk melegalkan permainan judi di daerahnya. 
Dari beberapa dampak positif dan negatif dari perjudian di atas, jika dianalisis lebih jauh, maka akan tampak bahwa dibanding manfaatnya, sejatinya madharat dari maisir/judi lebih besar. Dalam dampak positif disebutkan bahwa maisir/judi akan mamacu pertumbuhan ekonomi, atau dengan kata lain industri perjudian merupakan sektor yang menguntungkan bagi pemerintah, karena melalui sektor ini pajak bisa didapatkan dengan mudah, bisa menyediakan lapangan pekerjaan, dan secara umum meningkatkan pertumbuhan ekonomi. Akan tetapi hal ini, dalam pandangan Paul Samuelson dalam buku Luthfi Hamidi disebutkan bahwa maisir/judi sebenarnya tidak meningkatkan pertumbuhan ekonomi, karena judi tidak menghasilkan output, yang terjadi hanya perpindahan uang dan barang antar individu. Kritiknya judi hanya menghabiskan tenaga dan waktu, bahkan jika judi dimaksudkan untuk menghabiskan waktu (killing time) maka aktivitas ini secara agregat mengurangi pendapatan nasional (Hamidi, 2012, p. 228).

Kemudian, dalam dampak positif juga disebutkan bahwa maisir/judi bisa menjadi ajang hiburan. Hal ini juga sebenarnya tidak tepat, karena mereka yang berjudi ada rasa khawatir dan cemas di hatinya, lebih-lebih kalau perjudian yang dilakukan adalah illegal. Di dalam perjudian sekalipun ada investasi, tetapi juga sarat dengan spekulasi. Dalam buku Quranomics dijelaskan bahwa manfaat dan madharat judi sebagaimana dijelaskan dalam skema pro dan kontra terhadap perjudian adalah:(Hamidi, 2012, pp. 226-227)

\begin{tabular}{|l|l|l|}
\hline No & PRO & KONTRA \\
\hline 1 & $\begin{array}{l}\text { Rileksasi dan sumber rekreasi } \\
\text { orang dewasa }\end{array}$ & $\begin{array}{l}\text { Penjudi mengalami gangguan } \\
\text { irritabilitas, gastrointestinal, gangguan } \\
\text { tidur dan tekanan darah tinggi }\end{array}$ \\
\hline 2 & $\begin{array}{l}\text { Mengurangi stress dan } \\
\text { kebosanan }\end{array}$ & $\begin{array}{l}\text { Menyebabkan stress dan panik, } \\
\text { meningkatkan risiko tekanan darah } \\
\text { tinggi dan gangguan jantung }\end{array}$ \\
\hline 3 & $\begin{array}{l}\text { Meningkatkan kesehtan } \\
\text { emosional; merasa bebas, } \\
\text { merdeka, dan lebih percaya diri; } \\
\text { meningkatkan kreatifitas; } \\
\text { problem solving; meningkatkan } \\
\text { sense of humor; hidup lebih } \\
\text { menyenangkan }\end{array}$ & $\begin{array}{l}\text { Penurunan Kesehatan fisik: pusing } \\
\text { kronik, kesulitan bernagas, dada sesak, } \\
\text { penyakit jantung,kegemukan, } \\
\text { alkoholik, masalah gigi, mati rasa di } \\
\text { sekitar tangan dan kaki, impoten. }\end{array}$ \\
\hline 4 & $\begin{array}{l}\text { Bermimpi menjadi pemenang } \\
\text { judi bisa memperkaya kualitas }\end{array}$ & $\begin{array}{l}\text { Orang tua (16\% ayah dan 7 \% ibu) } \\
\text { penjudi meninggal Ketika anaknya }\end{array}$ \\
\hline
\end{tabular}




\begin{tabular}{|c|c|c|}
\hline & hidup & baru berusia 18 th \\
\hline 5 & $\begin{array}{llr}\text { Membantu pensiunan untuk } \\
\text { melawan penyakit lupa } \\
\text { (Alzheimer) karena otak terus } \\
\text { dipacu untuk aktif }\end{array}$ & $\begin{array}{l}\text { Penjudi yang kalah menjadikan anak } \\
\text { anak sebagai sasaran kekerasan fisik } \\
\text { dan sexual abuse }\end{array}$ \\
\hline
\end{tabular}

Kemudian dalam QS. Al-Maidah: 90-91, disebutkan bahwa maisir/perjudian adalah termasuk perbuatan syaitan yang tujuannya adalah untuk menebar kebencian dan memicu permusuhan. Hal ini juga selaras dengan fakta di lapangan. Selama ini, perjudian identik dengan kejahatan. Para pelaku judi (khususnya mereka yang kalah) seringkali melakukan perbuatan nekad, seperti merampok dan bahkan bunuh diri. Dalam sejarah perjudian tidak ada orang kaya karena berjudi, yang terjadi justru sebaliknya, orang menjadi miskin karena berjudi. Seharusnya mereka membelanjakan hartanya untuk kebaikan, bukan untuk berbuat keburukan misal menggunakan hartanya untuk berjudi (Kemenag RI, 2012a, pp. 323-324).

\section{E. Simpulan}

Maisir (judi) dimaknai dengan mendapatkan sesuatu atau keuntungan dengan sangat mudah tanpa kerja keras atau mendapat keuntungan tanpa bekerja. Istilah lain yang digunakan dalam al-Quran adalah kata ‘azlam`yang berarti praktek perjudian. Senada dengan di atas maisir adalah suatu permainan yang menempatkan salah satu pihak harus menanggung beban pihak lain. Maisir mengandung beberapa pengertian di antaranya: lunak, tunduk, keharusan, mudah, gampang, kaya, membagi-bagi, dan lainlain. Dengan pengertian bahwa maisir/judi merupakan upaya dan cara untuk mendapatkan rezeki dengan mudah, tanpa susah payah. Judi berbeda dengan spekulasi dan investasi walaupun di dalamnya sama-sama ada resiko dan keuntungan. Al-Quran menjelaskan pengharaman maisir (judi) dalam tiga ayat yaitu QS. Al-Baqarah 219, QS. Al- Maidah 90, dan 91, yang ketiganya menunjukan pentahapan pelarangan (pengharaman) judi. Al-Qur'an menyebutkan bahwa judi memiliki manfaat dan madharat, tetapi madharatnya jauh lebih besar dibanding manfaatnya. Hal ini sangat relevan dengan sudut pandang ekonomi; bahwa perjudian tidak meningkatkan pertumbuhan ekonomi, karena sebenarnya judi tidak menghasilkan output, yang terjadi 
hanya perpindahan uang dan barang antar individu. Lebih jauh, judi hanya menghabiskan tenaga dan waktu para pelakunya. Judi dalam keadaannya yang seperti ini (killing time), maka ia secara agregat sangat mengurangi pendapatan nasional sebuah negara.

\section{F. Daftar Pustaka}

Agama di Indonesia | Indonesia Investments. (n.d.). Retrieved December 24, 2020, from https://www.indonesia-investments.com/id/budaya/agama/item69?

Al Hamsyi, M. H. (1999). Tafsir Wa Bayan Mufrodat Al-Quran 'Ala Mushaf at Tajwid Ma'a Asbabun Nuzul Li as Suyuthi (I). Muassasah al Iman.

Al Mashri, R. Y. (2001). Al Maisir. Dar al Qalam.

Al-Ma'idah-المآئدة | Qur'an Kemenag. (n.d.). Retrieved December 25, 2020, from https://quran.kemenag.go.id/sura/5/90

Al-Maraghi, A. M. (2001). Tafsir Al-Maraghi (Jilid III). Darl Fikr.

Al-Qurthubiy. (1372). Al-Jami' li Ahkam al-Qur'an: Vol. Juz 3. Dar al-Syu'ub.

Ascarya. (2013). Akad\&Produk Bank Syariah (1st ed.). PT Raja Grafindo Persada.

Ash-Shabuni, M. A. (1980). Tafsiru Ayati Al-Ahkami Min Al-Qur'an (Juz 1). Maktabah al-Ghazali.

Aziz, N. (2020). Membumikan al-Qur'an Melalui Penafsiran Bahasa dan Sastra Bint As-syati'. LKKI Publisher.

Badan Pusat Statistik. (2010). Penduduk Menurut Wilayah dan Agama yang DianutIndonesia

[PDF]. https://pkub.kemenag.go.id/files/pkub/file/file/Data/zuqi1368036766.pdf

Balubun, D. D., Rahawarin, Y. F., Orun, Y., \& Notanubun, F. O. (2019). Tindak Pidana Judi Sabung Ayam Dalam Perspektif Budaya Dan Hukum. Patriot, 23-46.

Fariani, D., \& Irawan, D. (2020). Praktik Perlombaan Kicau Burung Dengan Merger Hadiah Dan Sinkronisasi Biaya Tiket Pendaftaran Dalam Perspektif Hukum Islam (Studi Kasus Di Lapangan Alam Pesona Tebas Kuala). Jurnal Studi Islam Lintas Negara (Journal of Cross Border Islamic Studies), 2(1), 45-61. 
Freeman, F. N. (1907). The Ethics Of Gambling (Vol. 18). International Journal Of Ethics.

Hamidi, M. L. (2012). The Crisis; Krisis Manalagi Yang Engkau Dustakan (Cet.I). Republika.

Hermawan, S. P. I. (2019). Studi Islam Nusantara. Yayasan Hj. Kartini Kudus.

Ini Alasan Relief Borobudur Soal Kehidupan Bebas Ditimbun. (2016, December 20). BorobudurNews. https://borobudurnews.com/ini-alasan-relief-borobudur-soalkehidupan-bebas-ditimbun/

Karim, A. (2004). Bank Islam: Analisis Fikih dan Keuangan (3rd ed.). Raja Grafindo Persada.

Kemenag RI. (2012a). Al-Qur'an dan Tafsirnya: Vol. juz 1,2,3. PT Sinergi Pustaka Indonesia.

Kemenag RI. (2012b). Tafsir Qur'an Tematik: Pembangunan Ekonomi Umat. PT Sinergi Pustaka Indonesia.

Ma’u, D. H. (2016). Judi sebagai Gejala Sosial (Perspektif Hukum Islam). Jurnal Ilmiah Al-Syir'ah, 5(2).

MEDIA, P. A. S., \& www.akurat.co. (2020, July). Ini Loh Kelebihan dan Kekurangan, Jika Indonesia Melegalkan Perjudian! akurat.co. https://akurat.co/ekonomi/id1166819-read-ini-loh-kelebihan-dan-kekurangan-jika-indonesia-melegalkanperjudian

Mustaqim, A. (2012). Epistemologi Tafsir Kontemporer (III). LKiS Group.

Mustaqim, A. (2013). Madzahibut Tafsir: Peta Metodologi Penafsiran Al-Qur'an Periode Klasik Hingga Kontemporer. Nun Pustaka.

Rohim, F. (2020). Tinjauan hukum pidana Islam terhadap Putusan Perjudian Bola Online: Studi Putusan Pengadilan Negeri Batam Nomor: 184/Pid. B/2018/PN. Btm [PhD Thesis]. UIN Sunan Ampel Surabaya.

Rudiansyah, R. (2020). Telaah Gharar, Riba, dan Maisir dalam Perspektif Transaksi Ekonomi Islam. Al-Huquq: Journal of Indonesian Islamic Economic Law, 2(1), 98113.

Sahroni, O., \& Karim, A. (2017). Maqashid Bisnis dan Keuangan Islam; Sintesis Fikih dan Ekonomi (Cet 3). Raja Grafindo Persada. 
Shihab, M. Q. (2004). Tafsir al-Mishbah (Pesan, Kesan, dan Keserasian al-Qur'an) (Vol. 3). Lentera Hati.

$\begin{array}{lll}\text { Statistik Kriminal } 2019 . & \text { pdf. }\end{array}$ https://www.bps.go.id/publication/2019/12/12/66c0114edb7517a33063871f/statisti k-kriminal-2019.html (n.d.). 